\title{
Moderate congenital adrenal hyperplasia in two girls diagnosed by newborn screening
}

\author{
Umiarkowana postać wrodzonego przerostu nadnerczy u dwóch dziewcząt zdiagnozowanych \\ w przesiewie noworodkowym
}

\author{
${ }^{1}$ Magdalena Banaszak-Ziemska, ${ }^{1}$ Elżbieta Małecka, ${ }^{2}$ Katarzyna Łacna, ${ }^{3}$ Maria Ginalska-Malinowska, \\ 1,4 Marek Niedziela
}

\author{
${ }^{1}$ Karol Jonscher's Clinical Hospital, Poznan University of Medical Sciences, Poznan, Poland \\ ${ }^{2}$ Center of Medical Genetics GENESIS, Poznan, Poland \\ ${ }^{3}$ Screening and Metabolic Diseases Department, Institute of Mother and Child, Warsaw, Poland \\ ${ }^{4}$ Department of Pediatric Endocrinology and Rheumatology, Institute of Pediatrics, Poznan University \\ of Medical Sciences, Poznan, Poland
}

\begin{abstract}
Introduction: Congenital adrenal hyperplasia (CAH) before the introducing a newborn screening was initially diagnosed based on clinical symptoms or positive family history and thereafter confirmed hormonal profiles.

Patients' report: We present two female newborns with atypical screening results born shortly after the introduction of neonatal screening for congenital adrenal hyperplasia in the Wielkopolska region. Female patients 1 and 2 were both born at term and discharged from neonatal departments without any suspicion of disease. After performing complete neonatal screening for $\mathrm{CAH}$, girls were admitted to the endocrine department for further investigations. In both cases, the girls did not exhibit characteristic symptoms of the disease. Using the Synacthen test, we observed an insufficient increase in cortisol and an abnormal increase in 17-OHP concentrations. The 24-hour urinary steroid profile analyzed by GC-MS confirmed the diagnosis. In both cases, treatment with hydrocortisone and fludrocortisone was initiated. Genetic evaluation confirmed mutations in the CYP21A2 gene.

Discussion and Conclusion: Newborn screening for $\mathrm{CAH}$ is useful for revealing a moderate form of $\mathrm{CAH}$ and indicates the need to start treatment in cases without typical signs of disease to prevent further virilization and the generation of a GnRH-independent precocious puberty. For nonobvious screening results, clinical information, including any data on virilization, is extremely helpful. Therefore, a careful assessment of newborns' genitalia in neonatal departments is important. The screening laboratory should be informed about any abnormalities to perform a complete screening immediately decreasing significantly the time between taking the paper sample and the final diagnosis.
\end{abstract}

Key words:

congenital adrenal hyperplasia, newborn screening.

\section{Streszczenie}

Wprowadzenie: Wrodzony przerost nadnerczy (WPN) przed wprowadzeniem przesiewu noworodkowego rozpoznawany był początkowo na podstawie objawów klinicznych lub dodatniego wywiadu rodzinnego potwierdzonym odpowiednimi badaniami.

Opis przypadków: Przedstawiono dwa noworodki płci żeńskiej, urodzone wkrótce po wprowadzeniu programu badań przesiewowych w kierunku WPN w Wielkopolsce, z nie całkiem typowymi wynikami badań przesiewowych. Pacjentki, odpowiednio 1 i 2 , urodzone o czasie, były wypisane z oddziałów noworodkowych bez podejrzenia o chorobę. Po wykonaniu kompletu badań przesiewowych dziewczynki były przyjęte na oddział endokrynologii dziecięcej w celu diagnostyki WPN. W obu przypadkach przy przyjęciu nie było typowych objawów klinicznych choroby. W teście z ACTH zaobserwowano brak rezerwy nadnerczowej w zakresie wydzielania kortyzolu oraz nieprawidłowy przyrost stężenia 17-OHP. W profilu steroidowym w dobowej zbiórce moczu metodą GC-MS potwierdzono rozpoznanie. U obu pacjentek włączono leczenie hydrokortyzonem i fludrokortyzonem. Analiza genetyczna potwierdziła mutacje w genie CYP21A2.

Dyskusja i wniosek: Badanie przesiewowe pozwoliło ujawnić miernie nasiloną klinicznie formę wrodzonego przerostu nadnerczy i rozpocząć leczenie substytucyjne u dwóch noworodków płci żeńskiej bez typowych objawów klinicznych. Postępowanie to pozwo- 
liło zapobiec pogłębianiu się wirylizacji u tych dziewcząt oraz wygenerowaniu GnRH-niezależnego przedwczesnego dojrzewania płciowego. Przy nietypowych wynikach badań przesiewowych bardzo istotne są dane kliniczne, szczególnie informacja o wirylizacji w obrębie narządów płciowych noworodka. Dlatego tak ważna jest wnikliwa ocena narządów płciowych zewnętrznych w oddziałach neonatologicznych i informowanie laboratoriów przesiewowych o każdej, nawet najmniejszej nieprawidłowości u dziecka. Pozwoli to przeprowadzić krótszą ścieżkę przesiewu, istotnie skracając czas do postawienia diagnozy.

\section{Słowa kluczowe:}

wrodzony przerost nadnerczy, badanie przesiewowe noworodka.

\section{Introduction}

Congenital adrenal hyperplasia $(\mathrm{CAH})$ is one of the most common hereditary autosomal recessive diseases in humans and is associated with defects in steroid biosynthesis. Deficiency of 21-hydroxylase activity is most common and is estimated to account for $90-95 \%$ of all $\mathrm{CAH}$ cases, whereas $5-8 \%$ of cases are associated with the deficiency of $11 \beta$-hydroxylase. Deficiency of other steroidogenesis enzymes such as $3 \beta$-hydroxysteroid dehydrogenase, 17 $\alpha$-hydroxylase and Steroidogenic Acute Regulatory Protein (STaR) are very rare. The range of symptoms in $\mathrm{CAH}$ vary widely from the mild form with acne, hirsutism, and problems with fertility that manifest later in life to the severe form with ambiguous genitalia, which is associated with an excess of sex steroids in females and deficiency of sex steroids in males, precocious puberty, delayed puberty, hypokalemic hypertension and ultimately life-threatening salt-loss syndrome. $\mathrm{CAH}$ due to deficiency of 21-hydroxylase may be manifested in the following clinical forms: classic form with salt-wasting (SW-CAH), classic form with simple virilization (SV-CAH) and a milder nonclassic form (NC-CAH) characterizes with late onset. Clinical severity is correlated with the type CYP21A2 gene mutation. Approximately $75 \%$ of classic form $\mathrm{CAH}$ cases suffer from aldosterone deficiency with failure to thrive, feeding problems, salt-wasting syndrome leading to life-threatening hypovolemia and shock. Newborns typically present with these symptoms in the $2^{\text {nd }}-3^{\text {rd }}$ week of life [1]. In Europe, the frequency of the occurrence of homozygotes with the classic form $\mathrm{CAH}$ ranges from 1:5000 to $1: 12000$, and the frequency of the nonclassic form is $1: 1000$. According to information from the first years of neonatal Polish screening, the frequency of $\mathrm{CAH}$ occurrence in Poland is $1: 14781[2,3]$. The carrier of the classic form is noted in 1:40 individuals in the European population, and nonclassic form is noted in 1:9 [4-6].

\section{Neonatal screening}

Pang et al. were the first to introduce neonatal screening based on 17-OHP measurements from filter paper in 1977 [7]. Worldwide guidelines from the Endocrine Society and European Society for Paediatric Endocrinology recommend to incorporate screening for 21-hydroxylase deficiency into all newborn screening programs [1]. Screening markedly reduces the time from birth to diagnosis [5, 8-10]. Patients with nonclassic $\mathrm{CAH}$ could also be recognized in screening, especially after incor- porating genetic analysis into the screening [11, 12]. Affected infants ascertained through screening have less severe hyponatremia $[10,13]$. The delay in the appropriate sex assignment of severely virilized females is also markedly reduced $[6,10]$. Evaluation of 17-OHP concentration is the first step of neonatal screening in all countries, but further steps may differ. Equally important is determining which parameter is used as a reference for 17-OHP concentration. The concentration of 17-OHP is more correlated with gestational age, but the determination of gestational age might be less reliable than birth weight [14]. In Wielkopolska, newborn screening for $\mathrm{CAH}$ was introduced in September 2016. Until the end of 2016, all of Poland was involved in this program [2]. The first step of the screening is to evaluate 17-OHP concentration from dried blood spots from filter paper taken on the $3^{\text {rd }}$ day of life using the fluoroimmunoassay (FIA) method in regional screening laboratories. In the Polish screening program, 17-OHP is assessed based on gestational age and day of sampling. Elevated results are verified by blood steroid profile by tandem mass spectrometry (LC/MS/MS) at the Institute of Mother and Child in Warsaw using samples on filter paper obtained on the $3^{\text {rd }}$ day of life and sent for screening for inborn metabolic defects. The following steroids are assessed in the blood steroid profile: 17-OHP, cortisol, 21-deoxycortisol, 11-deoxycortisol and androstenedione. Evaluation of the (17-OHP+androstenedione)/cortisol ratio and (17-OHP+21-deoxycortisol)/cortisol) ratio are also included in the LC/MS/MS screening results. Both of these ratios improve the specificity of the screening $[2,15]$. In preterm newborns, a retest of the $2^{\text {nd }}$ filter paper is necessary. Borderline and equivocal results of 17-OHP (FIA) and steroid profiles are also verified in the $2^{\text {nd }}$ filter paper. After that, the regional consultant for pediatric endocrinology is informed about the child suspected for $\mathrm{CAH}$. The newborn is subsequently admitted to the endocrine ward, and diagnosis is verified. The last step of the neonatal screening is the genetic analysis of the CYP21A2 gene at the Institute of Mother and Child in Warsaw.

\section{Patients' report}

We present two diagnostically difficult CAH female patients investigated in the first months of the neonatal screening in the Wielkopolska region, Poland.

Patient 1 was born as a $2^{\text {nd }}$ child (older brother is unaffected) to nonconsanguineous parents at the $40^{\text {th }}$ week of gestation with the birth weight of $3520 \mathrm{~g}$ and the birth length of $56 \mathrm{~cm}$. 
The patient scored 9-10 points on the Apgar scale. A girl was discharged from the neonatal department without any suspicion of disease. The screening filter paper was sampled twice on the $3^{\text {rd }}$ day of life and again on the $14^{\text {th }}$ day of life (blood steroid profiles in Warsaw were performed on the $11^{\text {th }}$ and the $25^{\text {th }}$ day of life, respectively). For both filter papers, 17-OHP (FIA) concentrations were slightly elevated (Table II). In blood steroid profiles (LC/MS/MS), 17-OHP concentrations were in the normal range, and androstenedione levels were reduced. The 21-deoxycortisol concentration was slightly elevated in the first LC/MS/MS and was normalized in the second LC/MS/MS analysis. The cortisol level was low and decreased over time. Therefore, the (17-OHP + androstendione/cortisol) ratio and the (17-OHP +21 deoxycortisol/cortisol) ratio were increased, especially in the second steroid profile (Table I). Given the inconclusive results, the child was urgently called to the endocrine ward. Upon admission (28 $8^{\text {th }}$ day of life), the weight was $3970 \mathrm{~g}$. Based on the patient's history, the girl was less active and required awakening for feeding. Upon physical examination, her state of nutrition was satisfactory, and there were no signs of dehydration. A tendency for marbling skin color was noted with hyperpigmentation of external genitalia and nipples. Only a small virilization was noticed, which was graded as the $1^{\text {st }}$ stage based on the Prader scale. At admission, the electrolyte concentrations were as follows: $132 \mathrm{mmol} / \mathrm{l} \mathrm{Na}$ (normal range 132-145) and $5,31 \mathrm{~K} \mathrm{mmol} / \mathrm{l}$ (normal range 3.1-5.1). We observed an insufficient increase in cortisol and an abnormal increase in 17-OHP concentration in the short-Synacthen test (36 ug/kg) (Table II). Concentrations of $\mathrm{ACTH}$, androstenedione, testosterone, and DHEA-S were greater than the upper limits (Table II). The steroid profile in the 24-hr urine collection was assessed by GC-MS and confirmed the diagnosis of 21-hydroxylase deficiency (Table III). On the $30^{\text {th }}$ day of life, hydrocortisone $(\mathrm{HC})$ treatment was started. HC was initially administered intravenously. After three days, the patient was switched to an oral regimen. Given that the sodium concentration was in the lower limit, fludrocortisone was also added. We diagnosed a classic form of simple virilizing/moderate congenital adrenal hyperplasia due to 21-hydroxylase deficiency. Karyotype was 46,XX. Genetic evaluation by MLPA (MRC-Holland: SALSA MLPA Probemix P050 CAH) detected two mutations in the CYP21A2 gene: heterozygous intron 2 splice variant I2G (HGVS nomenclature: NM 000500.7: c.293-13C > G) and heterozygous mutation p.I172N (HGVS nomenclature: NM_000500.7: c.515T>A; NP_000491.4: p.I172N).

Patient 2 was born as an only child to nonconsanguineous parents at the $40^{\text {th }}$ week of gestation with the birth weight of $3670 \mathrm{~g}$ and the birth length of $56 \mathrm{~cm}$. The patient scored 10 points on the Apgar scale. The girl was discharged from the neonatal department without any suspicion of disease. Filter paper obtained on the $3^{\text {rd }}$ day of life reached the Poznan screening laboratory 6 days later (the $9^{\text {th }}$ day of life) and the Warsaw screening laboratory in the next 5 days (the $14^{\text {th }}$ day of life). Elevated concentration of 17-OHP (61.71 nmol/l) suggested $\mathrm{CAH}$. In the blood steroid profile, 17-OHP and 21-deoxycortisol concentrations were elevated, whereas the cortisol concentration was at the lower limit of the normal range. The androstenedione concentration and the 11-deoxycortisol and (17-OHP+androstendione/cortisol) ratio were in the normal range, and only the (17-OHP +21 -deoxycortisol)/cortisol ratio was slightly elevated (Table I). The child was urgently called to the endocrine ward. At admission ( $24^{\text {th }}$ day of life), weight was $4000 \mathrm{~g}$. Physical examination revealed the following: eutrophic newborn, no signs of dehydration, active, hyperpigmentation of external genitalia and nipples, and $2^{\text {nd }}$ stage virilization based on Prader scale. At admission, the electrolyte concentration (134 mmol/l Na and 5,07 mmol/l K) were normal. We performed

Table I. 17-OHP (FIA) concentration and steroid profile from neonatal screening in both patients

\begin{tabular}{lllll}
\hline Parameters from neonatal screening & $\begin{array}{l}\text { Below standard } \\
\text { (persons) }\end{array}$ & $\begin{array}{l}\text { Below standard } \\
\text { (persons) }\end{array}$ & $\begin{array}{l}\text { Standard } \\
\text { (persons) }\end{array}$ & $\begin{array}{l}\text { Above standard } \\
\text { (persons) }\end{array}$ \\
\hline 17-OHP (FIA) (nmol/l) & 45.95 & 62.02 & 61.71 & $0.1-33$ \\
\hline 17-OHP MS/MS (nmol/l) & 3.58 & 11 & 30.4 & $0.1-14.8$ \\
\hline Cortisol MS/MS (nmol/l) & 2.4 & 0.1 & 19.9 & $11-4569$ \\
\hline 21-deoxycortisol MS/MS (nmol/l) & 16.8 & 3.82 & 43.8 & 5.9 \\
\hline 11-deoxycortisol MS/MS (nmol/l) & 1.55 & 0.58 & 0.76 & 85.2 \\
\hline Androstenedione MS/MS (nmol/l) & 0.57 & 0.03 & 4.06 & $1.75-32.65$ \\
\hline (17-OHP+androstenedione)/cortisol ratio MS/MS & 2.03 & 110.29 & 1.73 & $0.1-1.95$ \\
\hline (17-OHP+21-deoxycortisol)/cortisol ratio MS/MS & 9.99 & 148.2 & 3.73 & $0.1-1.95$ \\
\hline
\end{tabular}

17-OHP - 17-hydroxyprogesterone; FIA - fluoroimmunoassay method; MS-MS - tandem mass spectometry 
Table II. Concentration of hormones in plasma/serum

\begin{tabular}{|c|c|c|}
\hline Parameters & Patient 1 & Patient 2 \\
\hline $\begin{array}{l}\text { Cortisol in Synacthen test } \\
0^{\prime} \mathrm{min}(\mathrm{ng} / \mathrm{ml})\end{array}$ & 21 & 16 \\
\hline $\begin{array}{l}\text { Cortisol in Synacthen test } \\
30^{\prime} \mathrm{min}(\mathrm{ng} / \mathrm{ml})\end{array}$ & 28 & 27 \\
\hline $\begin{array}{l}\text { Cortisol in Synacthen test } \\
60^{\prime} \mathrm{min}(\mathrm{ng} / \mathrm{ml})\end{array}$ & 29 & 38 \\
\hline $\begin{array}{l}\text { 17-OHP in Synacthen test } \\
0^{\prime} \mathrm{min}(\mathrm{ng} / \mathrm{ml})\end{array}$ & 33.4 & 33.9 \\
\hline $\begin{array}{l}\text { 17-OHP in Synacthen test } \\
30^{\prime} \mathrm{min}(\mathrm{ng} / \mathrm{ml})\end{array}$ & 36.4 & 37.1 \\
\hline $\begin{array}{l}\text { 17-OHP in Synacthen test } \\
60^{\prime} \mathrm{min}(\mathrm{ng} / \mathrm{ml})\end{array}$ & 34.8 & 38.68 \\
\hline Androstenedione (ng/ml) & $\begin{array}{l}3.47 \\
(0.06-0.78)\end{array}$ & $\begin{array}{l}9.55 \\
(0.06-0.78)\end{array}$ \\
\hline DHEA-S ( $\mu \mathrm{mol} / \mathrm{l})$ & $\begin{array}{l}15.24 \\
(0.14-1)\end{array}$ & $\begin{array}{l}12.2 \\
(0.14-1)\end{array}$ \\
\hline Testosterone (nmol/l) & $\begin{array}{l}1.85 \\
(0.03-0.17)\end{array}$ & $\begin{array}{l}2.57 \\
(0.03-0.17)\end{array}$ \\
\hline ACTH (pg/ml) & $\begin{array}{l}110.5 \\
(10-60)\end{array}$ & $\begin{array}{l}420.9 \\
(10-60)\end{array}$ \\
\hline PRA (ng/ml/h) & - & $\begin{array}{l}5.5 \\
(4-37)\end{array}$ \\
\hline
\end{tabular}

17-OHP - 17-hydroxyprogesterone; DHEA-S - dehydroepiandrosterone sulphate; PRA - plasma renin activity

a short-Synacthen test $(36 \mu \mathrm{g} / \mathrm{kg})$. We observed an insufficient increase in cortisol and an abnormal increase in 17-OHP concentration (Table II). Basal concentrations of ACTH, androstenedione, testosterone, and DHEA-S were significantly elevated (Table II). The steroid profile in the 24-hr urine collection (GC-MS) confirmed the diagnosis of 21-hydroxylase deficiency (Table III). On the $25^{\text {th }}$ day of life, hydrocortisone $(\mathrm{HC})$ treatment was started. HC was initially administered intravenously and then switched to an oral regimen after three days. Given that the sodium concentration was in the lower normal limit, fludrocortisone was added. We diagnosed a classic form of simple virilizing/moderate congenital adrenal hyperplasia due to 21-hydroxylase deficiency. Karyotype was 46,XX. Genetic evaluation by MLPA (MRC-Holland: SALSA MLPA Probemix P050 CAH) detected two abnormalities: heterozygous deletion of the exon 4 in the CYP21A2 gene and heterozygous duplication of the exon 4 in CYP21A1P pseudogene.

\section{Discussion}

The introduction of a new screening method for the population offers new benefits. We would such as to highlight that both patients described in this paper were discharged from neonatal departments without any suspicion of disease although the symptoms of virilization were described a few weeks later and expressed to a greater degree in patient 2. The question arises as to whether virilization was present at birth but missed by neonatologists or developed over time. The first option is more likely compared with its development in such a short period, i.e., from birth until the $28^{\text {th }}$ and $24^{\text {th }}$ day in the two patients, separately. Some previous reports have demonstrated that greater than $50 \%$ of females had an incorrect clinical evaluation of the virilization features [10, 12-13]. In Poland, in 5 of 31 female cases identified in the first three years of neonatal $\mathrm{CAH}$ screening, there were no data about virilization in the newborn hospital documentation [3]. In all these 5 cases, initially small abnormalities found in the first filter paper were worsened in time with each subsequent studies. Afterward, clinical and laboratory verification in the endocrine department allowed the diagnosis of moderate $\mathrm{CAH}$ in these girls. Eventually, virilization (the $1^{\text {st }}$ to $3^{\text {rd }}$ Prader stage) was identified despite not being noticed in neonatal unit earlier [3].

As a standard, a single 17-OHP (FIA) called 'singlet' is performed. Increased values are retested in the next working day as a doublet. When 17-OHP (FIA) elevation is confirmed again, a steroid profile (LC/MS/MS) is performed. If the screening laboratory has information about virilization, both investigations, namely 17-OHP (FIA) in a triplet and steroid profile (LC/ MS/MS), are performed simultaneously to confirm or exclude $\mathrm{CAH}$ as soon as possible. To fulfill the neonatal screening function, the time between filter paper sampling and diagnosis of the disease should be as short as possible. In the study by Thil'en, et al., the median age at diagnosis was 11 days (range, 6-127 days), and the median age of detection was eight days for SW-CAH vs. 24 days for SV-CAH (10). In the Swedish population, the time between sampling and the time for recall decreased from 7 days (median) at the beginning of the study to 4 days (median) after 1991 [10]. Additionally, at the beginning of the screening program in Poland, we often noted an increase in time between filter paper sampling and delivery to the screening laboratory that was associated with the use of regular mail [3]. The use of regular mail explained the delay in analyses in our patients. The first filter paper of patient 1 was recorded in the Poznan Regional Screening Laboratory after four days and in Warsaw one day later. However, the $2^{\text {nd }}$ filter paper sample obtained on the $14^{\text {th }}$ day of life was recorded in Warsaw after ten days. Regarding patient 2, the filter paper arrived at the regional laboratory after 6 days and to Warsaw after 11 days. Therefore, in the first patient, we received information about the suspicion of $\mathrm{CAH}$ within 26 days of the newborn's life. This information was received within 16 days of life for the second patient. Since last year, the filter papers have been sent via courier mail from neonatal departments to the screening laboratories. Therefore, such delays are no longer observed. 
Table III. Steroid profile by GC/MS in 24th hour urine collection analyzed in The Children's Memorial Health Institute Warsaw

\begin{tabular}{|c|c|c|c|c|}
\hline Hormone/metabolite & $\begin{array}{l}\text { Patient } 1 \\
(\mu \mathrm{g} / 24 \mathrm{~h})\end{array}$ & Normal range & $\begin{array}{l}\text { Patient } 2 \\
(\mu \mathrm{g} / 24 \mathrm{~h})\end{array}$ & Normal range \\
\hline AN (androsterone) & 32.9 & $2-20$ & 25.2 & $1-10$ \\
\hline ET (etiocholanolone) & 2.2 & $0-3$ & 1.1 & $1-5$ \\
\hline 11-OAN/ET (11-cetoandrosterone/etiocholanolone) & 15.4 & $0.5-6.5$ & 30.0 & $5-20$ \\
\hline 11-OHAN (11-hydroxy-androsterone) & 109.1 & $3-24$ & 44.0 & $2-20$ \\
\hline 11-OHET (11-hydroxy-etiocholanolone) & 0.0 & $0-3$ & 0.9 & $0-3$ \\
\hline ET/AN & 0.1 & & 0.0 & \\
\hline DHA (dehydroepiandrosterone) & 2.2 & $0-3$ & 11.3 & $1-10$ \\
\hline 5-AND (5-androstenediol) & 1.8 & $0-12$ & 1.7 & $1-10$ \\
\hline 16 $\alpha-\mathrm{OHDHA}(16 \alpha$-hydroxy-DHA) & 467.5 & $7-230$ & 744.2 & $135-500$ \\
\hline An-3-ol (5-androstenetriol) & 129.6 & $15-150$ & 128.3 & $40-600$ \\
\hline 5-PT (5-pregnenetriol) & 38.9 & $0-26$ & 40.3 & $2-20$ \\
\hline 16-OHPN (16a-hydroxy-pregnenolone) & 884.7 & $0-140$ & 1010.6 & $110-495$ \\
\hline 17-OHPN (5ß) (17-hydroxy-pregnanolone) & 165.3 & $1-16$ & 123.6 & $4-19$ \\
\hline 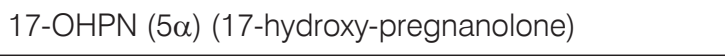 & 134.5 & $0.5-9$ & 72.1 & $0.5-9$ \\
\hline PT (pregnanetriol) & 312.3 & $3-28$ & 121.8 & $5-21$ \\
\hline PTN (pregnanetriolone) & 1087.1 & $0.2-10$ & 427.7 & $0-5$ \\
\hline PD (pregnanediol) & 32.8 & $0.2-10$ & 17 & $2-20$ \\
\hline E1 (estrone) & 0.0 & & 0.0 & \\
\hline E2 (estradiol) & 0.0 & & 0.0 & \\
\hline E3 (estriol) & 0.0 & & 0.0 & \\
\hline THS (tetrahydro-11-deoxycortisol) & 4.0 & $1-11$ & 6.7 & $1-3$ \\
\hline THDOC (tetrahydro-11-deoxycorticosterone) & 0.0 & $0-1$ & 0.0 & $0-1$ \\
\hline THA (tetrahydro-11-dehydrocorticosterone) & 0.0 & $5-50$ & 0.0 & $5-30$ \\
\hline Allo-THA (allo-tetrahydro-11-dehydrocorticosterone) & 0.0 & $10-60$ & 0.0 & $15-90$ \\
\hline THB (tetrahydro-corticosterone) & 0.0 & $0-8$ & 0.0 & $0-8$ \\
\hline Allo-THB (allo-tetrahydro-corticosterone) & 0.0 & $0-40$ & 0.0 & $0-40$ \\
\hline THaldo (tetrahydro-aldosterone) & 6.7 & $4-25$ & 3.1 & $4-12$ \\
\hline THE (tetrahydro-cortisone) & 94.4 & $150-400$ & 72.9 & $38-408$ \\
\hline THF (tetrahydro-cortisol) & 8.8 & $3-68$ & 6.8 & \\
\hline Allo-THF (allo-tetrahydrocortisol) & 17.2 & $7-260$ & 15.6 & \\
\hline THF/alloTHF & 0.5 & & 0.4 & \\
\hline THF+alloTHF/THE & 0.3 & $<0.8$ & 0.3 & \\
\hline
\end{tabular}


Table III. Steroid profile by GC/MS in 24th hour urine collection analyzed in The Children's Memorial Health Institute Warsaw (cont.)

\begin{tabular}{|c|c|c|c|c|}
\hline Hormone/metabolite & $\begin{array}{l}\text { Patient } 1 \\
\text { ( } \mathrm{g} / 24 \mathrm{~h})\end{array}$ & Normal range & $\begin{array}{l}\text { Patient } 2 \\
\text { ( } \mathrm{gg} / 24 \mathrm{~h})\end{array}$ & Normal range \\
\hline$\alpha$-CTN ( $\alpha$-cortolone) & 22.8 & $20-130$ & 17.8 & $20-100$ \\
\hline$\beta$-CTN ( $\beta$-cortolone) & 57.9 & $25-155$ & 51.5 & $20-100$ \\
\hline$\beta$-CT ( $\beta$-cortol) & 27.0 & $5-40$ & 19.5 & $5-10$ \\
\hline$\alpha$-CT ( $\alpha$-cortol) & 52.1 & $4-42$ & 20.0 & $5-20$ \\
\hline E (free cortisone) & 12.6 & $5-45$ & 11.7 & $5-20$ \\
\hline F (free cortisol) & 10.5 & $2-16$ & 25.1 & $3-20$ \\
\hline $\mathrm{F} / \mathrm{E}$ & 0.8 & $0.3-0.75$ & 2.2 & \\
\hline $6 \beta$-OHF (6ß-hydrocortisol) & 0.0 & & 0.0 & \\
\hline $20 \alpha$-DHF (20 $/ \beta$-dihydrocortisol) & 0.0 & & 0.0 & \\
\hline
\end{tabular}

Findings from both our patients indicate that $\mathrm{CAH}$ is occasionally difficult to diagnose based on screening. In the first patient, results obtained from the first filter paper were not obvious. The diagnosis was complicated by the fact that in a phone call with the neonatal department any virilization was excluded. The slight increase in 17-OHP (FIA) concentration and increased 21-deoxycortisol levels with normal androgen levels in the first steroid profile needed to be repeated. Eventually, increased 17-OHP (FIA) concentrations in the second filter paper, significantly decreased cortisol levels in LC/MS/MS, and significantly increased steroid ratios in LC/MS/MS suggested 21-hydroxylase deficiency in this neonate (Table I). Further evaluation of androgen concentrations in plasma and the study of steroid profiles in 24-h urine collection facilitated the diagnosis of SV-CAH (Tables II and III). In this case, the urinary steroid profile analysis was the most helpful in establishing a correct diagnosis. Genetic analysis confirmed the diagnosis definitively. Unclear results in the first patient were associated with SV-CAH. Lack of information about virilization on the first filter paper extended the time of analysis, which caused a delay in the diagnosis. Approximately $70 \%$ of CYP21A2 disease-causing mutations are pseudogene-derived variants due to gene conversion, involving the transfer of deleterious mutations from pseudogene to the active CYP21A2 gene [17]. Most patients with CAH are compound heterozygotes carrying two different diseasecausing mutations. The phenotype is defined by the mutation retaining the most enzyme activity [18]. Similar to that noted in patient 1 , SV-CAH occurs in approximately $76 \%$ of patients with $\mathrm{CAH}$ who carry the p.I172N mutation on one allele and a severe mutation on the other, whereas $23 \%$ of these patients present with SW-CAH. The intron $2 \mathrm{G}$ variant primarily results in SW-CAH. However, $20 \%$ of patients have an SV phenotype [18]. Genetic analysis in patient 2 revealed a carrier state. Nevertheless, clinical evaluation, the insufficient increase in cortisol levels, and an abnormal increase in the 17-OHP concentration in the Synacthen test allowed the diagnosis of SV-CAH. These results suggested the presence of an additional mutation that has not been detected by the given method to date. Incorporating the molecular analysis of the CYP21A2 gene into neonatal screening can improve screening specificity and may also aid in the clinical management of the disease $[5,19]$. Such analysis helps to discriminate between real cases and false positives and to clarify borderline cases, including NC-CAH patients with persistent elevated 17-OHP concentrations. The analysis can also be used to diagnose carriers of NC-CAH $[5,12,19]$.

In summary, we report two girls with SV-CAH who received a substantial benefit from neonatal screening. They were discharged from the neonatal department without any suspicion of $\mathrm{CAH}$ despite mild virilization. During verification, CAH testing with Synacthen revealed a decreased response in cortisol synthesis, so these patients manifest adrenal insufficiency in challenging situations. Early diagnosis allowed the administration of more rapid treatment to prevent further virilization and development of precocious puberty.

\section{Conclusions}

As we demonstrate, a milder form of $\mathrm{CAH}$ may experience great benefit from this screening, especially when these cases present with mild virilization that could be missed. However, this condition should not be missed. Careful evaluation of external genitals in neonatological departments is critical. In female newborns, physicians should be focused on the even smallest signs of the virilization. The Screening Regional Laboratory should be informed about each case with even mild virilization of external genitals or with skin hyperpigmentation to perform a complete screening immediately decreasing significantly the time between taking the paper sample and the final diagnosis. 


\section{References}

1. Speiser PW, Azziz R, Baskin LS et al. Congenital Adrenal Hyperplasia Due to Steroid 21-Hydroxylase Deficiency: An Endocrine Society Clinical Practice Guideline. J Clin Endocrinol Metab 2010; 95: 4133-4160. doi: 10.1210/jc.2009-2631.

2. Ołtarzewski M. Newborn Screening in Poland-2018. Postępy Neonatol 2018; 2018: 111-122.

3. Ginalska-Malinowska M, Ołtarzewski M, Gzowska J, Głąb-Jabłońska $\mathrm{E}$. Wrodzony przerost nadnerczy oraz badania przesiewowe wrodzonego przerostu nadnerczy - informacje niezbędne dla pediatrów w rejonie. Klinika Pediatryczna 2019; 27: 1-6.

4. White PC, Speiser PW. Congenital adrenal hyperplasia due to 21-hydroxylase deficiency. Endocr Rev 2000; 21: 245-291. doi: 10.1210/edrv.21.3.0398.

5. Balsamo A, Cacciari E, Piazzi S, et al. Congenital adrenal hyperplasia: neonatal mass screening compared with clinical diagnosis only in the Emilia-Romagna region of Italy, 1980-1995. Pediatrics 1996; 98 (3 Pt 1): 362-367.

6. Pang SY, Wallace MA, Hofman L, et al. Worldwide experience in newborn screening for classical congenital adrenal hyperplasia due to 21-hydroxylase deficiency. Pediatrics 1988; 81: 866-874.

7. Pang S, Hotchkiss J, Drash AL, et al. Microfilter paper method for 17 alpha-hydroxyprogesterone radioimmunoassay: its application for rapid screening for congenital adrenal hyperplasia. J Clin Endocrinol Metab 1977; 45: 1003-1008. doi: 10.1210/jcem-45-5-1003.

8. Brosnan PG, Brosnan CA, Kemp SF, et al. Effect of newborn screening for congenital adrenal hyperplasia. Arch Pediatr Adolesc Med 1999; 153: 1272-1278. doi: 10.1001/archpedi.153.12.1272.

9. Therrell BL, Berenbaum SA, Manter-Kapanke $V$ et al. Results of screening 1.9 million Texas newborns for 21-hydroxylase-deficient congenital adrenal hyperplasia. Pediatrics 1998; 101 (4 Pt 1): 583590. doi: 10.1542/peds.101.4.583.

10. Thil'en A, Nordenström A, Hagenfeldt $L$, et al. Benefits of neonatal screening for congenital adrenal hyperplasia (21-hydroxylase deficiency) in Sweden. Pediatrics 1998; 101: E11. doi: 10.1542/ peds.101.4.e11.
11. Witchel SF. Newborn screening for congenital adrenal hyperplasia: beyond 17-hydroxyprogesteron concentrations. J Pediatr (Rio J) 2019; 95: 257-259. doi: 10.1016/j.jped.2018.06.003.

12. Kopacek C, Prado MJ, da Silva CMD, et al. Clinical and molecular profile of newborns with confirmed or suspicious congenital adrenal hyperplasia detected after a public screening program implementation. J Pediatr (Rio J) 2019; 95: 282-290. doi: 10.1016/j. jped.2018.03.003.

13. Van der Kamp HJ, Noordam K, Elvers B, et al. Newborn screening for congenital adrenal hyperplasia in the Netherlands. Pediatrics 2001; 108: 1320-1324. DOI: 10.1542/peds.108.6.1320.

14. Kamp VD, Oudshoorn CGM, Elvers BH, et al. Cutoff Levels of $17-\alpha$-Hydroxyprogesterone in Neonatal Screening for Congenital Adrenal Hyperplasia Should Be Based on Gestational Age Rather Than on Birth Weight. J Clin Endocrinol Metab 2005; 90: 39043907. doi: 10.1210/jc.2004-2136.

15. Janzen N, Peter M, Sander S, et al. Newborn Screening for Congenital Adrenal Hyperplasia: Additional Steroid Profile using Liquid Chromatography-Tandem Mass Spectrometry. J Clin Endocrinol Metab 2007; 92: 2581-2589. doi: 10.1210/jc.2006-2890.

16. Speiser PW, Dupont J, Zhu D, et al. Disease expression and molecular genotype in congenital adrenal hyperplasia due to 21-hydroxylase deficiency. J Clin Invest 1992; 90: 584-595. doi: 10.1172/ JCl115897.

17. Speiser PW, White PC. Congenital adrenal hyperplasia. N Engl J Med 2003; 349: 776-788. doi: 10.1056/NEJMra021561.

18. New MI, Abraham M, Gonzalez B, et al. Genotype-phenotype correlation in 1,507 families with congenital adrenal hyperplasia owing to 21-hydroxylase deficiency. Proc Natl Acad Sci U S A 2013; 110: 2611-2616. doi: 10.1073/pnas.1300057110.

19. Silveira EL, Elnecave RH, dos Santos EP, et al. Molecular analysis of CYP21A2 can optimize the follow-up of positive results in newborn screening for congenital adrenal hyperplasia. Clin Genet 2009; 76: 503-510. doi: 10.1111/j.1399-0004.2009.01274.x. 